\title{
The Ku Klux Klan of the 1920s in the Midwest and West: A Review Essay
}

\section{ROBERT NEYMEYER}

Women of the Klan: Racism and Gender in the 1920s, by Kathleen M. Blee. Berkeley: University of California Press, 1991. viii, 228 pp. Illustrations, notes, index. $\$ 24.95$ cloth.

The Invisible Empire in the West: Toward a New Historical Appraisal of the Ku Klux Klan of the 1920s, edited by Shawn Lay. Urbana: University of Illinois Press, 1992. 230 pp. Tables, notes, index. $\$ 32.50$ cloth.

Citizen Klansmen: The Ku Klux Klan in Indiana, 1921-1928, by Leonard J. Moore. Chapel Hill: University of North Carolina Press, 1991. Illustrations, maps, notes, appendix, bibliography, index. $\$ 34.95$ cloth.

The Dragon and the Cross: The Rise and Fall of the Ku Klux Klan in Middle America, by Richard K. Tucker. Hamden, CT: Shoe String Press, Archon Books, 1991. xi, 224 pp. Illustrations, notes, appendix, bibliography, index. $\$ 27.50$ cloth.

THE IMAGE OF THE KU KLUX KLAN evokes negative and angry.responses from most people living in the Midwest and West today. Yet seventy years ago the Klan of the 1920sthe so-called second Klan-had great appeal to mainstream, middle America in these areas. Nearly three million people joined the ranks of the Invisible Empire in the years from 1921 to 1925 , making the second Klan a powerful political and social force from Ohio to Oregon.

The traditional explanation for this grass-roots phenomenon was that Klan members were marginal people from rural areas who were resisting the incursion of urban values. The

THE ANNALS OF IOWA 51 (Fall 1992). CThe State Historical Society of Iowa, 1992. 
focus of their anger was the newly arrived immigrant infestation which was responsible for changing American society. Not only was the Klan anti-Catholic and anti-Jewish, but it continued to use violence and vigilantism to intimidate the AfricanAmerican population. From this rural, bigoted, and predominantly fundamentalist base, the second Klan attempted to force the nation to adopt its xenophobic solutions.

By the mid-1980s, scholars had begun to challenge this traditional interpretation of the second Klan. Case studies of Youngstown, Memphis, Orange County, and Colorado found that most Klansmen in the 1920 s were not marginal, fanatical men from the rural lower class. Using newly located Klan membership lists and newspapers, census data, congressional hearings, and oral history interviews, historians began to construct a different profile. The new Klansman was socially and economically stable, civic minded, from a mainstream Protestant church, and likely to live almost anywhere, including in large cities. He was primarily concerned with local social problems rather than ethnic and racial issues. He called for the enforcement of prohibition laws, the elimination of gambling and prostitution, and the revival of quality education. The villains were no longer immigrants, but the commercial and industrial elite that had taken control of state and local government in the years after 1900. That leadership had been content to allow, and often profited from, the undermining of traditional values. The new values, often promoted under the guise of boosterism or economic progress, became the focus for the anger of a middle and lower middle class that believed the people had lost control of their government and that government was no longer responsive to their needs or demands.

Historians have discovered a common pattern in the rise and fall of local Klan units, or klaverns. First, outside Klan operatives secretly recruited members, usually from among small businessmen, fraternal groups, or the clergy. Once a group was formed, these members brought in trustworthy friends and associates during a campaign highlighted by cross burnings, parades, and public meetings. Once established, the Klan would contribute to charities and churches and promote 100 percent Americanism to gain respectability. The critical turning point came when a klavern found that it could not implement 
its moral reform agenda. Klansmen then either ran for office or supported candidates, usually Republicans, who were willing to support Klan policies. From 1923 through 1925, Klansmen or their surrogates were elected to hundreds of offices, ranging from governor to school board member.

There were several reasons for the Klan's inability to sustain its popularity. The most obvious was the failure of Klan leadership, which was often corrupt and immoral. D. C. Stephenson, whose alcoholic and sexual excesses demoralized the Indiana Klan, was the most sensational, but not the only example. In power, Klan politicians proved to be too dogmatic and uncompromising to implement their programs. But the problems went beyond inept leadership. Once the Klan entered politics, its policy of secrecy became a liability because such a policy appeared to be incompatible with the principles of open debate and freedom of expression within a democracy. Finally, serious opposition to the Klan came from liberals and socialists who condemned the Klan's racism and bigotry as well as. from those politicians who had been turned out during the Klan's moral crusade. The collapse of the Klan after 1925 was so complete that by 1930 there were only a handful of klaverns operating outside of the South.

The story of the Klan continues to attract attention. Several recent books have made valuable contributions to the literature. Leonard Moore's Citizen Klansmen: The Ku Klux Klan in Indiana, 1921-1928 is the most comprehensive study of the second Klan to date. The Invisible Empire, with its three hundred thousand members, was very visible in Indiana, where Klansmen openly held elected office and membership in the Klan was not as secretive as elsewhere. Moore had the good fortune to locate complete, statewide Klan membership lists which, when compared with census data and city directories, allowed him to establish a comprehensive socioeconomic profile. His findings confirm the revisionist interpretation that most Klansmen were financially successful, politically active, belonged to fraternal groups, and attended mainstream Protestant churches; in other words, they reflected a cross-section of Indiana society. Klan members developed a sense of community, or klannishness, through participation in parades, conventions, and social affairs. Their sense of unity and commitment was particularly 
strong in the years between 1922 and 1925 as they worked to regain control of local government and restore traditional values.

Moore has also provided a more complete description of the "insiders" who opposed the Klan. Late nineteenth-century industrialization had produced a new community elite. The new industrialists, their managers, and the commercial leaders who were spawned from the factory economy displaced the traditional business leaders in large cities and even in smaller towns. Without a commitment to the community, they tended to depersonalize relationships and ignore moral and social traditions. By the 1920s, Moore contends, this group was so deeply involved in boosterism, political machines, and even bootlegging and gambling that they became a serious threat to the average citizen. Because the same group also controlled city hall and the police, they were able to suppress any reform effort. In this seemingly desperate situation, the Klan appeared as the only alternative to regain control of local affairs. Whether this was a neopopulist movement or the continuation of the progressive movement, it was nonetheless a legitimate effort to make government accountable.

The Indiana Klan, however, cannot be used as a model for the entire nation. A collection of essays edited by Shawn Lay demonstrates how an opportunistic Klan fashioned its message to address local issues in the West. In The Invisible Empire in the West: Towards a New Historical Appraisal of the Ku Klux Klan of the 1920s, six historians describe western klaverns in Denver, El Paso, Anaheim, Salt Lake City, and Eugene and La Grande in Oregon. The contributors focused on a set of common issues to provide a comparative framework.

The typical Klansman and klavern in these studies resembled those Moore found in Indiana. The organizational pattern also remained the same. Members were recruited through fraternal and business groups; community concerns about crime and immorality were exploited; bigotry and prejudice were appealed to; and local klaverns became involved in politics. The klaverns' demise was the result of political ineptitude and scandal on the part of the leadership and strong resistance from leaders who were being threatened or had been displaced. 
Despite these similarities, there were many ways in which the western klaverns differed from those in Indiana. Western klaverns made little use of economic boycotts, only occasionally resorted to overt violence, placed less emphasis on klannishness and charities, and held fewer mass meetings, or konklaves. Western Klansmen generally kept their membership secret and were less successful politically than midwestern klansmen. Local situations provided more diversity. In Salt Lake City strong opposition from the Mormon church and an anti-mask law kept membership low. In Anaheim and Eugene the Klan message was carried by young businessmen seeking to break the power of the old commercial sector. In El Paso the Klan turned to the Democratic party as the vehicle of political change. Most klaverns based their agenda on local issues rather than on national concerns such as prohibition, and they sought more pragmatic solutions. What might have worked in Kokomo was not necessarily useful in La Grange.

Moore and the contributors to The Invisible Empire in the West perpetuate one major omission in the studies of the second Klan. Women have received only passing mention, and no one has analyzed the role of women in the Klan. Kathleen Blee's Women of the Klan: Racism and Gender in the 1920s provides the first interpretive account of women's involvement in the Klan. Like Moore, Blee focused on the Indiana Klan, though she did not have the good fortune to locate membership lists identifying the more than one hundred thousand women she estimates were members of the Klan's women's auxiliary in Indiana. However, by using newspaper articles, obituaries, and some oral history, she has been able to construct a profile of a typical Klanswoman.

The image parallels that of Moore's Klansman except that the women exhibited a greater concern for the moral deterioration of society. Many Klanswomen had been involved in the temperance movement, and others were political activists. Given this background, Blee contends that some Klanswomen used the Klan to further a women's rights agenda. Since women were admitted into the Klan primarily for their dues and voting power, they used this as leverage to establish an independent organization, Women of the Ku Klux Klan (WKKK). Although there were many restrictions on the WKKK, its leaders worked 
to establish a voting block to preserve the gains of the Nineteenth Amendment and to push for more reforms. This assertion, based on a small sampling and dependent on the writings of only a few WKKK leaders, needs to be investigated in other situations, but it is consistent with the idea that interest groups found the Klan a convenient vehicle to further their agenda.

Blee uses the second Klan as a basis for a discussion of gender and race in politics. Unlike some revisionists, she contends that white male supremacy was at the core of both the Reconstruction Klan and the second Klan. However, while white female vulnerability was an acceptable concept in the postCivil War period, by the 1920 s Klansmen had discovered that women were no longer willing to be defined in that role. But in recruiting women and granting them status within the organization, Klansmen created expectations they could not meet or control. As a result, Klanswomen used the pure white womanhood issue to demand greater equality. Thus, in Blee's terms, a gender equality movement found a home in a reactionary social movement. Although internal tensions and contradictions, as well as external forces, forced an early end to this situation, Blee suggests that its existence should prompt historians to reevaluate the issue of gender politics in other organizations.

Richard Tucker's The Dragon and the Cross provides a distinct contrast to the above works. In this popular history, based on the traditional view of the Klan, the author sees the Klan's program as one based on ethnic and religious fanaticism. The main focus of the book, however, is the Grand Dragon of Indiana, D. C. Stephenson. His meteoric rise to power was based on fraud, intimidation, and insatiable greed. At the height of his power he was able to dictate policy to state politicians and officials and become wealthy through his monopoly on the sale of robes and hoods. It was his alcoholism and sexual debauchery that led to his downfall. Stephenson kidnapped, drugged, and raped Madge Oberholtzer, a government clerical worker. Her suicide, the direct result of suffering and anguish from the attack, led to the arrest and conviction of the Grand Dragon. The scandal played an important role in the rapid demise of the Klan in Indiana. Tucker's account of the events, albeit somewhat sensationalized, captures the dramatic difference between the Klan leadership and the rank-and-file mem- 
bership. [See also the book notice on Grand Dragon: D. C. Stephenson and the Ku Klux Klan, by M. William Lutholtz, later in this issue. $-E d$.]

It is difficult, from the perspective of the 1990s, to understand the popularity of the second Klan. What appeal did it have that attracted so many people so quickly? The attraction was not limited to Indiana or the West. Iowa had a strong Klan presence with klaverns in Anamosa, Creston, Des Moines, Dubuque, Greenfield, Perry, and Vinton, to name only a few. Kay Johnson, in her master's thesis in history at the University of Iowa, "The Ku Klux Klan in Iowa: A Study of Intolerance," described the strong Des Moines klavern, which had the support of city officials and police. On the other extreme, her list of Greenfield Klansmen portrays a cross-section of small-town Iowa. Across the state, Klansmen silently delivered, during church services, hundreds of money purses to congregations full of respectable people. Part of Iowa was certainly receptive to the Invisible Empire's message. Studying the Klan's appeal to Iowa men and women in the light of these studies of the Klan in states to the east and west of Iowa would enrich the historical understanding of this mass movement.

The growing volume of research already has done much to define the Klan of the 1920s. Yet there are questions that remain unresolved. One area that needs further study is the role of race and Klan leadership in starting klaverns. The revisionists tend to discount the importance of racism in explaining why people signed up with the Klan. But the initial pitch most people heard dealt with intolerance towards AfricanAmericans, Hispanics, or Chinese. Before Klan recruiters identified the appropriate local issue to exploit, listeners received a heavy dose of what Klan leaders knew best. Related to this is the issue of demagoguery. The Klan's charismatic speakers represented one of the movement's strengths. The speakers' motivation was a share of each new member's dues, but their calling was public speaking. Both Moore and the contributors to the Lay volume make reference to powerful speakers and their ability to reach new members. The question is, did recruiters first attract members to the Klan for issues other than moral reform? If, indeed, people joined to rid society of its social cancers, at what point did they that realize the Klan would be a useful 
vehicle to accomplish this? At some point someone, most likely not a Klan recruiter, had to recognize the potential and move the klavern in that direction. It is evident this did occur, but it is not clear how and when it did.

The Klan also needs to be placed in a broader historical perspective. Moore, Lay's contributors, and Blee all recognize that there are similarities between the Klan and national movements such as populism, progressivism, and women's rights. Yet there is no consensus on whether the Klan represented a desire to revive the temperance effort, or if it was a grass-roots insurgency movement similar to populism. The argument that the Klan was a conveyance for feminism remains to be tested. Perhaps the opening of the 1920 census and comparisons with both the Huey Long and Robert La Follette organizations might improve our understanding of the Klan as a major reform effort.

If the Klan cannot be categorized at the national level, there are regional structures that can be applied. Andrew Cayton and Peter Onuf's recent book, The Midwest and the Nation: Rethinking the History of an American Region (1990), offers a framework that could be used to explain the Indiana situation. After a century of success, midwestern small-town capitalism was displaced by corporate industrialism in the 1890 s. But the inhabitants failed to realize, or admit, that structural changes had taken place, and they continued to believe that the nation remained a mirror image of themselves-white, Protestant, middle-class, and Republican. Even when they had to come to terms with reality, midwesterners thought they could recreate, much as they had done in populating the western frontier, a world that made sense and in which people had the power to effect change. An extension of the thesis suggests that once midwesterners recognized that the new industrial and commercial leaders would not allow this, they turned to the Klan as the only force that appeared to have the power to confront the entrenched elite. The goal remained, of course, to revive nineteenth-century bourgeois capitalist society.

The short life and ultimate failure of the second Klan has led some historians to consider it an insignificant event. However, it takes on new and greater importance when one considers that such a movement might reappear. Richard Tucker, more 
the journalist than historian, suggests that it is not inconceivable that a small but well-organized group or perhaps even an individual might be able to duplicate the Klan's success. By appealing to emotional social issues and encouraging a "mad as hell" response to an unresponsive government, an opportunistic group might find itself, as the Klan did, at the head of a mass political movement. In recognizing that the Ku Klux Klan of the 1920 s was not an aberration and by understanding how it came to power, perhaps Americans can learn from the lessons of the past. 
Copyright of Annals of Iowa is the property of State of Iowa, by \& through the State Historical Society of Iowa and its content may not be copied or emailed to multiple sites or posted to a listserv without the copyright holder's express written permission. However, users may print, download, or email articles for individual use. 